\title{
IMPLIKASI TATANAN NORMAL BARU TERHADAP KEHIDUPAN SOSIAL KEMASYARAKATAN
}

\author{
Dian Herdiana ${ }^{1}$, Supriatna Nurul ${ }^{2}$
}

1)2) Sekolah Tinggi Ilmu Administrasi (STIA) Cimahi

kyberdian@gmail.com

Received: 8 June 2020 ～Reviewed: 1 July 2020 | Accepted: 20 July 2020

\begin{abstract}
ABSTRAK
Tatanan normal baru merupakan kebijakan pemerintah dalam upaya keberlanjutan kegiatan masyarakat yang aman dari penyebaran COVID-19, masyarakat diharuskan mematuhi protokol kesehatan dalam menyelenggarakan kehidupan sosial kemasyarakatan. Implikasinya yaitu tuntutan bagi masyarakat untuk mengubah pola interaksi dalam kehidupan sosial kemasyarakatan yang selama ini ada. Didasarkan kepada pemahaman tersebut, artikel ini ditujukan untuk menggambarkan tatanan normal baru dalam kehidupan sosial kemasyarakatan serta tantangan apa yang muncul dalam penerapan tatanan normal baru tersebut. Metode yang digunakan dalam penulisan artikel ini yaitu metode analisis deskriptif dengan pendekatan kualitatif, data diperoleh melalui pengumpulan data sekunder yang terdiri dari buku, artikel jurnal, peraturan perundangan dan laman web. Teknik analisis data meliputi reduksi data, penyajian data dan penarikan kesimpulan. Hasil penelitian menunjukan bahwa perubahan dalam tatanan normal baru terkait kepada interaksi individu dengan lingkungannya yang terdiri dari lingkungan keluarga, lingkungan kerabat, lingkungan tempat kerja, lingkungan tempat pemenuhan kebutuhan pokok dan lingkungan tempat hiburan. Dalam konteks lingkungan keluarga setiap anggota keluarga harus mempraktekan tatanan normal baru dengan menerapkan perilaku hidup sehat dan bersih di dalam rumah, dalam konteks interaksi sosial diorientasikan kepada interaksi yang menjaga jarak dan menggunakan masker mulut. Tantangan yang muncul menyangkut kepada 3 (tiga) hal yaitu isi kebijakan, para pelaksana dan kelompok sasaran.
\end{abstract}

Kata Kunci: COVID-19, Normal Baru, Kehidupan Kemasyarakatan, Kebijakan

Korespondensi:

Sekolah Tinggi Ilmu Administrasi (STIA) Cimahi

Jl. Ibu Ganirah No.148, Cibeber, Kecamatan. 


\begin{abstract}
The new normal is a government policy in the effort to sustain community activities that are safe from the spread of COVID-19, the community is required to comply with health protocols in organizing social life. The implication is the demand for the community to change the pattern of interaction in social life that has existed. Based on this understanding, this article is intended to describe the new normal in social life and the challenges that arise in the implementation of the new normal. The method used is descriptive analysis method with a qualitative approach, data obtained through secondary data collection consisting of books, journal articles, laws and web pages. Data analysis techniques include data reduction, data display and conclusion drawing. The results revealed that the changes in the new normal related to the interaction of individuals with their environment consisting of family environment, relatives, workplace environment, market environment and entertainment environment. In the context of the family environment, each family member must practice the new normal by implementing healthy and clean living behaviours in the home, in the context of social interaction oriented towards interactions that maintain distance and use a mouth mask. The challenges that arise are related to 3 (three) things, namely the contents of the policy, the implementers and the target group.
\end{abstract}

Keywords: COVID-19, New Normal, Social Life, Policy

\title{
PENDAHULUAN
}

Wabah COVID-19 yang menyebar ke banyak negara di awal tahun 2020 berdampak kepada hampir seluruh aspek kehidupan seperti berdampak kepada aspek ekonomi dan aspek sosial. Berbagai negara telah berupaya dalam menanggulangi penyebaran COVID-19 baik melalui kebijakan lockdown maupun kebijakan social distancing, upaya tersebut di beberapa negara telah memberikan hasil kepada penurunan penyebaran COVID-19 yang mana penduduk yang terinfeksi COVID-19 telah berkurang secara signifikan (Center for Tropical Medicine UGM, 2020; Fang, Weedon, \& Handley, 2020).

Keberhasilan penanggulangan COVID-19 di beberapa negara diikuti dengan upaya pemulihan aspek ekonomi dan aspek sosial yang selama pandemi COVID-19 mengalami stagnasi, kebijakan yang diambil oleh pemerintah di negara-negara tersebut disebut dengan istilah new normal atau tatanan normal baru yang mana diartikan sebagai keberlanjutan aktivitas dalam suatu negara terdampak COVID-19 setelah adanya penurunan angka infeksi COVID-19 terhadap masyarakat. Kondisi tersebut oleh pemerintah di negara bersangkutan dianggap aman bagi penyelenggaraan aktivitas masyarakat khususnya aktivitas di ruang publik 
yang menghadirkan interaksi sosial antar warga masyarakat (David, Collins, \& Winfield, 2020; Keogh, 2020).

Kebijakan new normal didasarkan kepada pertimbangan bahwa COVID-19 tidak akan hilang dalam waktu dekat sebagaimana hasil kajian yang dilakukan oleh Badan kesehatan Dunia WHO (Gunia, 2020), sehingga menjadi tidak mungkin untuk menghentikan aktivitas ekonomi dan sosial sampai dengan tidak adalagi penyebaran COVID-19 yang mana hal ini dapat mengancam keberlanjutan pertumbuhan dan pembangunan suatu negara. Didasarkan kepada pemahaman tersebut maka alternatif kebijakan yang muncul yaitu melanjutkan kegiatan ekonomi dan sosial ketika penyebaran COVID-19 dianggap aman bagi keberlanjutan aktivitas ekonomi dan sosial dengan tetap adanya sikap kesiap-siagaan yang ditujukan oleh berbagi pihak terhadap potensi penyebaran COVID-19.

Berbagai ukuran yang digunakan dalam menentukan tingkat aman bagi keberlanjutan ekonomi dan sosial didasarkan kepada pertimbangan masing-masing negara, akan tetapi WHO memberikan pedoman untuk menentukan tingkat aman atau disebut sebagai panduan keberlanjutan hidup new normal yang mana disyaratkan memenuhi setidaknya kriteria berikut: Pertama, adanya hasil kajian yang menunjukan keberhasilan upaya pengendalian transmisi COVID-19. Kedua, adanya kelayakan kapasitas sistem kesehatan. Ketiga, meminimalkan risiko dalam kerentanan yang tinggi. Keempat, upaya pencegahan secara terpadu di lingkungan kerja. Kelima, manajemen pengelolaan risiko yang baik. Keenam, adanya peran aktif dan keterlibatan masyarakat dalam penyelenggaraan new normal (World Health Organization, 2020).

Kriteria yang dibuat oleh WHO tersebut diharapkan dapat menjadi pedoman bagi keberlangsungan tatanan norma baru bagi negara-negara yang terdampak wabah COVID-19 yang ingin melanjutkan kembali aktivitas kehidupan di negaranya, sehingga dengan mempraktikan syarat sebagaimana diatur WHO tersebut akan mampu menciptakan sinergitas antara upaya penanggulangan penyebaran COVID-19 dengan pemulihan sektor ekonomi dan sosial yang terdampak COVID-19.

Pemberlakuan tatanan normal baru yang diterapkan di berbagai negara di dunia diikuti pula dengan penerapan tatanan normal baru oleh pemerintah Indonesia yang mana pemerintah 
menyatakan bahwa diperlukan adanya usaha untuk memulihkan atau mengembalikan keberlanjutan aktivitas ekonomi dan sosial meskipun COVID-19 tidak akan hilang dalam waktu dekat. Pemerintah Indonesia setidaknya menetapkan tiga kriteria bagi daerah-daerah yang akan melaksanakan tatanan normal baru yaitu: Pertama, adanya tingkat penularan COVID-19 R0 (basic reproductive number) dibawah angka 1 (satu) atau tingkat penularan COVID-19 berada dibawah 1 (satu) orang. Kedua, adanya penetapan indikator kesehatan yang mana jumlah kasus infeksi COVID-19 tidak melebihi dari 60\% jumlah infrastruktur kesehatan yang digunakan di masing-masing daerah. Ketiga, adanya jumlah tes terhadap COVID-19 bagi masyarakat yang layak dan memadai disesuaikan dengan cakupan jumlah penduduk di tiaptiap daerah (Hakim, 2020a).

Penetapan kebijakan tatanan normal baru yang diterapkan di daerah-daerah yang telah dinyatakan layak oleh pemerintah akan berimplikasi kepada berbagai aspek kehidupan. Dalam aspek ekonomi adanya aturan baik bagi para pelaku usaha maupun bagi masyarakat untuk menerapkan prinsip protokol kesehatan yang diatur dalam kebijakan tatanan normal baru dalam menjalankan aktivitas ekonominya, begitu pula dalam aspek sosial yang mana relasi sosial khususnya yang dilakukan di ruang publik harus didasarkan pula kepada prinsip protokol kesehatan sehingga diharapkan dengan adanya penerapan tatanan normal baru dapat menghasilkan sinergitas keberlanjutan aktivitas ekonomi dan sosial masyarakat dengan upaya penanggulangan COVID-19 di masing-masing daerah.

Implikasi dari tatanan normal baru yang paling dirasakan masyarakat yaitu kepada kehidupan sosial kemasyarakatan. Sebelum adanya COVID-19 masyarakat sudah terbiasa melakukan interaksi sosial dengan intensitas yang tinggi, dalam prosesnya tidak sedikit masyarakat yang abai terhadap praktek pola hidup sehat ketika melakukan interaksi sosial. Dengan adanya protokol kesehatan dalam melaksanakan tatanan normal baru maka masyarakat dalam melakukan interaksi sosial harus mampu beradaptasi seperti menggunakan masker, rajin mencuci tangan dan menjaga jarak dengan orang lain.

Perubahan pola interaksi sosial dalam kehidupan sosial kemasyarakatan saat ini mendorong masyarakat untuk senantiasa mempraktekan perilaku hidup sehat dan bersih, mengingat dalam pelaksanaan kebijakan tatanan normal baru masyarakat dituntut untuk berperan aktif mempraktekan pola hidup yang baru, tanpa adanya ketaatan dari masyarakat 
sebagai subjek utama dalam pelaksanaan kebijakan tatanan normal baru maka tatanan normal baru yang dibuat oleh pemerintah tersebut tidak akan dapat berjalan sebagaimana tujuan yang telah ditetapkan.

Didasarkan kepada pemahaman tersebut, maka artikel ini ditujukan untuk menguraikan secara lebih mendalam mengenai tatanan baru seperti apa yang ada dalam pelaksanaan kebijakan normal baru serta faktor apa saja yang dapat mempengaruhi kelancaran penyelenggaraan tatanan normal baru dalam penyelenggaraan kehidupan sosial kemasyarakatan. Pendekatan kualitatif dengan metode analisis deskriptif digunakan sebagai metode penelitian dalam artikel ini. Pengumpulan data dalam penulisan ini menggunakan studi dokumentasi yang mana data diperoleh dari sumber sekunder berupa buku, jurnal, peraturan perundang-undangan, laman web dan sumber relevan lainnya. Teknik analisis data dilakukan melalui 3 (tiga) tahap sebagaimana pendapat dari Creswell (2007) yang meliputi tahap reduksi data, tahap penyajian data dan tahap penarikan kesimpulan. Sedangkan pengujian keabsahan data dilakukan melalui proses check, re-check dan cross-check antara data yang satu dengan data yang lainnya (Nawawi, 2007; Sugiyono, 2013) sehingga akan menghasilkan data yang valid. Analisis mengenai tatanan normal baru yang dikaji dalam aspek kehidupan sosial kemasyarakatan sebagaimana dimaksud di atas, diharapkan mampu menjadi gambaran dan bahan masukan alternatif bagi para pemangku kepentingan khususnya bagi pemerintah dalam upayanya menanggulangi penyebaran COVID-19 melalui instrumen kebijakan tatanan normal baru.

\section{PEMBAHASAN}

Pembahasan dalam artikel ini dibagi kedalam 2 (dua) bagian utama, yaitu: Pertama, penjelasan mengenai tatanan sosial baru dalam kehidupan masyarakat di masa COVID-19. Kedua, tantangan seperti apa yang muncul dalam proses penerapan tatanan normal baru. Analisis lebih rinci mengenai kedua bagian tersebut dapat dijelaskan sebagai berikut:

\section{Tatanan Sosial Baru dalam Kehidupan Masyarakat di Masa COVID-19}

Tatanan sosial merupakan lingkungan sosial yang mana individu-individu melakukan interaksi satu dengan yang lainnya. Tatanan sosial secara bahasa dibangun atas dasar kata tatanan yang memiliki korelasi erat dengan kata "order" yang diartikan sistem nilai yang dibangun dan dipatuhi oleh anggota masyarakat (Frank, 1944) dan kata sosial yang berarti 
berhubungan dengan kemasyarakatan atau sifat-sifat kemasyarakatan (Alwi, 2007). Berdasarkan kepada pemahaman tersebut maka tatanan sosial memiliki 4 (empat) unsur, yaitu: identitas yang berkenaan dengan ciri dari individu, kedudukan yang berhubungan dengan status sosial, peran yang berkenaan dengan tindakan dan norma yang berkenaan dengan nilai-nilai.

Tatanan sosial baru dalam konteks COVID-19, menurut pandangan penulis memiliki artian sebagai berikut: Pertama, nilai dasar yang diakui dan dipatuhi bersama yang dalam hal ini yaitu adanya aturan kebijakan tatanan normal baru beserta dengan ketentuan yang ada di dalamnya seperti menjaga jarak antar sesama warga di ruang publik dan penggunaan masker. Kedua, kedudukan individu dalam struktur sosial semisal apakah sebagai anggota masyarakat, Ketua RT, Kepala Desa dan lain sebagainya yang akan dikaitkan dengan tuntutan peran yang akan dijalankan yang dalam konteks ini berkaitan dengan tatanan normal baru. Ketiga, peran yang berkaitan dengan suatu harapan dari adanya kedudukan individu dalam struktur sosial, seperti peran Kepala Desa yang harus melakukan sosialisasi dan edukasi kepada masyarakat mengenai tatanan normal baru. Keempat, identitas individu yang mana adanya kedudukan, peran dalam menjalankan tatanan normal baru menjadikan individu tersebut memiliki ciri yang membedakannya dengan individu lain yang mengindahkan tatanan normal baru.

Seorang individu dalam tatanan sosial dikaitkan dengan kehidupan normal baru di masa COVID-19 akan senantiasa berkaitan dengan kegiatan individu tersebut yang berhubungan dengan kedudukan dan perannya dalam tatanan di masyarakat. Tatanan sosial dalam konteks normal baru dalam praktiknya tidak bisa dilakukan oleh seorang individu semata, tetapi memerlukan dukungan semua masyarakat sehingga lingkungan tempat seorang individu berinteraksi dengan yang lainnya memiliki kesamaan norma yang ditaati bersama, hal ini menjadi penting dikarenakan ketaatan kepada aturan yang sama akan benar-benar menciptakan tatanan normal yang baru dalam upaya penanggulangan COVID-19. Penjelasan mengenai kegiatan individu dalam tatanan normal baru dapat dijelaskan melalui gambar berikut ini: 


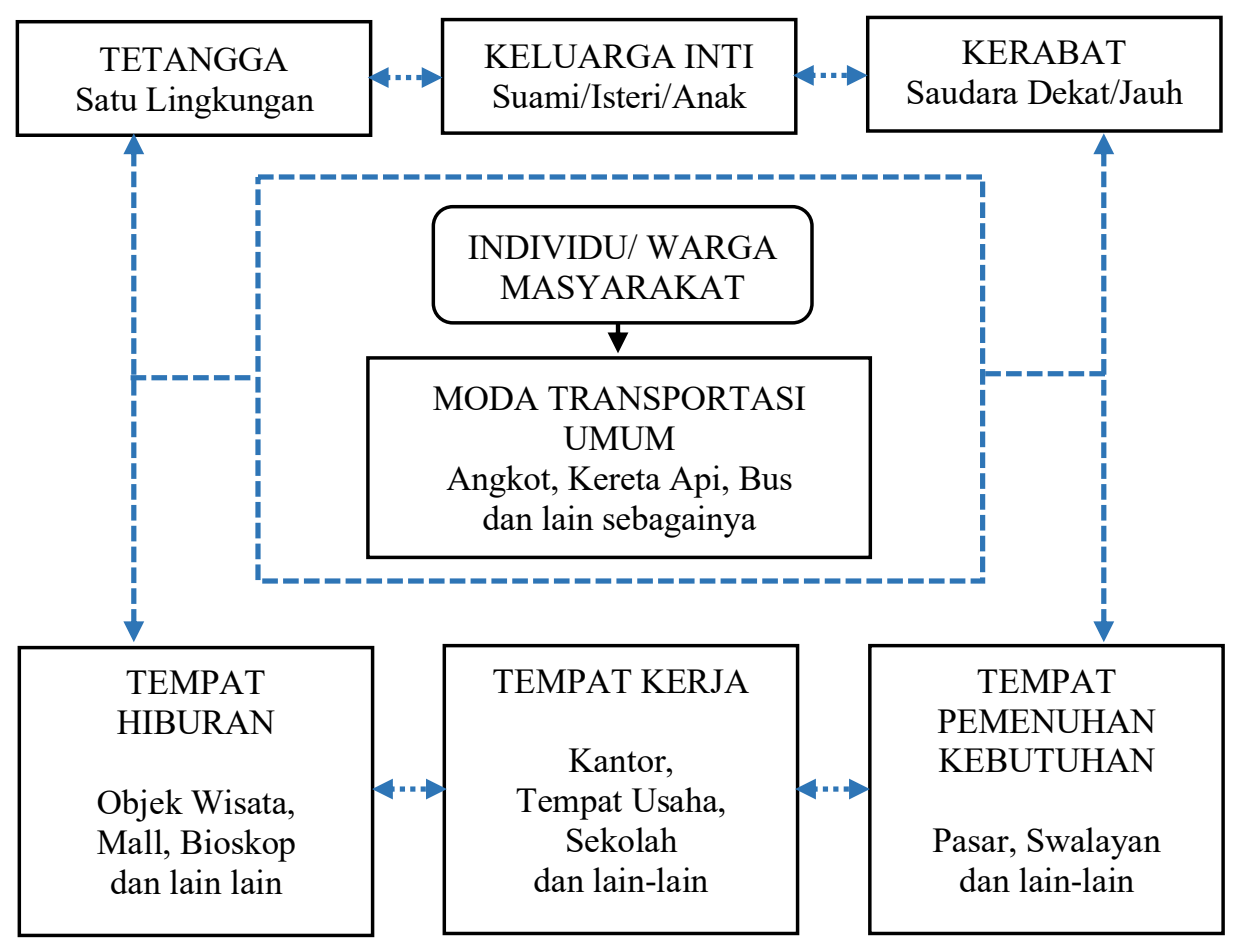

Gambar 1: Alur Interaksi Sosial dalam Tatanan Normal Baru

(Sumber: Analisis Penulis, 2020)

Berdasarkan kepada pemahaman tersebut maka seorang individu dalam melaksanakan kegiatannya akan selalu berada dalam lingkungan sosial tertentu baik yang lingkupnya kecil maupun yang lingkupnya besar. Aktivitas seorang individu dalam lingkungan tersebut tidak akan memiliki lagi kesamaan dengan sebelum adanya COVID-19, tatanan normal baru dalam suatu lingkungan seorang individu diartikan sebagai adanya nilai-nilai baru yang harus ditaati baik oleh individu yang bersangkutan maupun oleh individu lainnya yang berada di lingkungan tersebut. Berdasarkan kepada gambar 1 di atas setidaknya terdapat 6 (enam) lingkungan yang mana seorang individu akan melakukan kegiatannya, penjelasan keenam lingkungan tersebut sebagai berikut:

\section{Lingkungan Keluarga Inti}

Seorang individu merupakan unit terkecil yang membentuk suatu masyarakat yang bersifat tunggal/mandiri dan tidak bisa dibagi dalam unit yang lebih kecil lagi, seorang individu berasal dari anggota keluarga inti yang memiliki peran baik itu sebagai seorang suami, isteri 
maupun anak, dalam lingkungan keluarga ini seorang individu akan melakukan interaksi dengan anggota keluarga inti lainnya (Kusumadewi, 2010; Mustafa, 2011). Keluarga inti menjadi tempat interaksi seorang individu dengan intensitas yang tinggi terlebih di masa COVID-19 yang mana adanya ketentuan untuk melakukan aktivitas di rumah maka seorang individu menghabiskan sebagian besar waktunya di lingkungan rumah.

Keluarga inti dikaitkan dengan tatanan normal baru harus menjadi lingkungan pertama yang mana setiap anggotanya menyadari adanya norma-norma baru yang harus ditaati bersama, seorang suami/isteri atau anak harus mampu membangun pemahaman satu dengan lainnya mengenai aktivitas yang dilakukan dalam tatanan norma baru, lebih lanjut orang tua harus memberikan edukasi kepada anak mengenai bagaimana pola kegiatan yang harus dilakukan didasarkan kepada tatanan normal baru tersebut, baik di lingkungan rumah maupun di ruang publik atau lingkungan sosial. Dengan adanya kesadaran akan kehidupan dalam tatanan normal baru di tingkat keluarga, maka diharapkan akan berimplikasi kepada aktivitas individu yang bersangkutan untuk senantiasa mentaati kebijakan protokol kesehatan COVID-19 di berbagai lingkungan sosial.

\section{Lingkungan Rumah/Tetangga}

Lingkungan rumah menjadi lingkungan pertama diluar lingkungan keluarga inti yang mana seorang individu memiliki peluang untuk berinteraksi satu dengan yang lainnya (Hayati \& Yuswandi, 2019). Di lingkungan perdesaan, intensitas komunikasi antar warga masyarakat/tetangga menjadi lebih intens dibandingkan dengan masyarakat yang ada di kota (Angkasawati, 2015), sehingga dalam konteks ini pola interaksi dalam tatanan normal baru akan jauh lebih dirasakan bagi mereka yang berada di perdesaan, meskipun demikian baik masyarakat yang ada di kota maupun masyarakat yang ada di desa melakukan interaksi sosial di lingkungan rumahnya. Berdasarkan kepada hal tersebut maka membangun interaksi sosial yang didasarkan kepada tatanan normal baru dalam menanggulangi COVID-19 menjadi mutlak dilakukan bahkan harus menjadi suatu kewajaran baru.

Interaksi sosial seorang individu dengan tetangga harus didasarkan kepada pemahaman bersama akan ketaatan kepada aturan tatanan normal baru yang harus dijalankan serta harus pula memiliki kesamaan keinginan dan tujuan agar upaya interaksi sosial yang dilakukan 
berdasar kepada upaya menciptakan lingkungan perumahan yang bersih dan mempraktekan pola hidup sehat yang salah satu dampaknya akan mengurangi lingkungan tersebut dari potensi penyebaran COVID-19.

\section{Lingkungan Kerabat}

Saudara memiliki relasi khusus dari seorang individu yang didasarkan kepada adanya keterkaitan darah/keturunan. Dalam konteks Indonesia, saudara menjadi lingkungan kedua setelah keluarga inti yang mana tidak hanya memunculkan keterikatan yang erat, tetapi juga dapat membentuk harmonisasi dalam sistem kekerabatan (Munir, 2015; Yigibalom, 2013). Interaksi fisik antar seorang individu dengan kerabat tidak bisa dihindari, bahkan dapat dilakukan secara intens, khususnya dalam kegiatan keluarga seperti perayaan agama atau acara pernikahan. Intensitas interaksi tersebut apabila dikaitkan dengan konteks tatanan normal baru maka memberikan peluang besar terhadap penyebaran COVID-19 apabila interaksi yang dilakukan tidak didasarkan atas kesadaran mematuhi protokol kesehatan COVID-19.

Uraian tersebut di atas mendorong pemahaman bahwa pola interaksi seorang individu dengan kerabat lainnya harus dilakukan secara berbeda dalam tatanan normal baru. Seorang individu dengan saudara-saudaranya harus memiliki pemahaman yang sama akan perlunya perubahan kegiatan interaksi fisik/silaturahmi dalam tatanan normal baru, intensitas interaksi secara fisik dapat diminimalisir dengan pemanfaatan Teknologi Informasi dan Komunikasi (TIK) seperti pemanfaatan video call atau jejaring sosial yang menghadirkan interaksi sosial secara virtual tanpa mengurangi makna yang terkandung dalam kegiatan keluarga tersebut. Dalam tataran praktis, adanya kebutuhan untuk melakukan kegiatan keluarga/silaturahmi yang membuka peluang interaksi secara fisik seperti menghadiri acara pernikahan harus didasarkan kepada kesadaran bahwa kegiatan tersebut harus dilakukan secara singkat, meminimalkan kontak fisik serta didasarkan sepenuhya kepada kewaspadaan terhadap potensi penularan COVID-19.

\section{Lingkungan Tempat Kerja}

Seorang individu dalam menjalankan aktivitasnya tidak terlepas dari suatu pekerjaan guna menunjang pemenuhan kebutuhan hidupnya. Aktivitas pekerjaan baik di sektor formal seperti di sebuah perkantoran atau di sektor informal seperti pedagang di pasar memungkinkan untuk adanya interaksi sosial diantara satu dengan yang lainnya, atas dasar tersebut maka 
lingkungan tempat kerja harus memberikan rasa aman dari penyebaran COVID-19. Pemberlakuan kebijakan tatanan normal baru di dalam lingkungan pekerjaan harus disikapi sebagai suatu upaya keberlanjutan aktivitas usaha sehingga para pekerja baik sebagai pekerja formal maupun para pekerja informal mampu menjalankan tugasnya masing-masing secara optimal.

Tempat kerja harus menjadi tempat yang aman bagi para pekerja dalam melaksanakan kegiatannya baik dari segi kenyamanan maupun dari segi kesehatan, sehingga aktivitas yang selama ini dilakukan dapat berjalan dengan normal, di sisi lain para pekerja harus memiliki pemahaman dan kesedaran akan pentingnya menjaga kesehatan selagi bekerja sehingga akan mampu menciptakan produktivitas kerja yang aman dari penyebaran COVID-19. Dalam tatanan normal baru yang membedakan dari keadaan sebelumnya di lingkungan kerja yaitu intensitas interaksi sosial dan jumlah anggota dalam satu tempat kerja yang sama harus dibatasi, sehingga tidak menciptakan sesak atau kerumunan di tempat bekerja, dengan begitu aktivitas seorang individu ketika sedang bekerja akan tetap aman dan dapat meminimalisir dari adanya penularan COVID-19.

\section{Lingkungan Tempat Pemenuhan Kebutuhan Pokok}

Seorang individu akan berusaha agar kebutuhan pokoknya dapat dipenuhi, dalam prosesnya seorang individu akan melakukan pembelian kebutuhan pokok baik di pasar, swalayan dan tempat penjualan kebutuhan pokok sejenis lainnya. Adanya penyebaran COVID19 di lingkungan pasar, khususnya pasar tradisional yang berakibat kepada penutupan aktivitas jual beli di pasar seperti penutupan beberapa pasar di Jakarta akibat lebih dari 250 orang pedagang terinfeksi COVID-19 harus dijadikan bahan evaluasi guna membenahi sistem transaksi jual beli yang dilakukan di pasar yang sepenuhnya didasarkan kepada protokol kesehatan aman dari COVID-19 (Sari, 2020). Baik penjual maupun pembeli harus memiliki pengetahuan dan ketaatan terhadap kebijakan tatanan normal baru yang harus dipraktekan selama melakukan transaksi jual beli di pasar.

Pasar dalam konteks Indonesia baik pasar tradisional maupun pasar yang dikelola secara modern menjadi bagian dari aktivitas pemenuhan kebutuhan pokok penduduk. Pasar di satu sisi harus dapat berperan memenuhi kebutuhan pokok masyarakat, di sisi lain pasar harus menjadi tempat yang aman dan mampu meminimalisir potensi penularan COVID-19. 
Perkembangan Teknologi Informasi dan Komunikasi (TIK) dikaitkan dengan kebijakan tatanan normal baru telah memberikan alternatif kepada warga masyarakat akan adanya pilihan berbelanja kebutuhan pokok yang tidak hanya harus secara fisik mendatangi pasar atau supermarket, tetapi dapat dilakukan melalui aplikasi daring/online yang mana masyarakat tetap dapat memenuhi kebutuhan pokoknya. Di sisi lain aplikasi belanja daring/online juga mampu meminimalisir interaksi sosial yang akan terjadi di pusat perbelanjaan kebutuhan pokok, sehingga diharapkan potensi penularan COVID-19 di pusat perbelanjaan seperti pasar mampu diminimalisir.

\section{Lingkungan Tempat Hiburan}

Seorang individu dengan latar belakang berbeda akan membutuhkan hiburan, meskipun jenis dan intensitas tuntutan terhadap hiburan bisa berbeda antara satu dengan yang lainnya. Seorang individu di masa tatanan normal baru akan melakukan aktivitas dalam pemenuhan hiburannya, sehingga dalam pemenuhan kebutuhannya tersebut harus didasarkan kepada kebijakan tatanan normal baru yang mana prinsip dasar pemenuhan kebutuhan akan hiburan harus didasarkan kepada kesiagaan terhadap penyebaran COVID-19 yang antara lain yaitu: Pertama, meminimalisir intensitas dari aktivitas liburan. Kedua, meminimalisir jumlah rombongan peserta liburan dan memastikan tempat liburan yang dituju aman dan mempraktekan protokol kesehatan. Ketiga, individu dan anggota lainnya harus mempraktekan prinsip ketaatan terhadap aturan tatanan norma baru dengan senantiasa menjaga jarak dan memakai alat perlindungan diri selama berada di tempat hiburan. Uraian lebih rinci dari ketiga hal tersebut dapat dijelaskan sebagai berikut:

Pertama, meminimalisir intensitas aktivitas liburan yang mana seorang individu harus memahami bahwa kondisi di masa tatanan normal baru tidak memberikan keleluasaan untuk melakukan liburan, terlebih lagi tidak adanya jaminan tempat liburan atau objek wisata yang akan dikunjungi bebas dari penularan infeksi COVID-19, dengan mengurangi intensitas liburan maka akan mengurangi pula kemungkinan individu tersebut untuk terinfeksi COVID19 di tempat liburan.

Kedua, meminimalisir jumlah rombongan dan memastikan tempat liburan aman. Hal ini ditujukan agar liburan yang dilakukan dapat dikelola dengan baik serta sebagai antisipasi apabila tempat liburan yang dikunjungi terdapat banyak orang yang tidak menjamin adanya 
kepastian tidak adanya proses penularan COVID-19, kunjungan ke tempat liburan dalam jumlah yang kecil akan memudahkan dalam pengendalian dan pengawasan terhadap anggota rombongan yang tengah melakukan liburan.

Ketiga, mempraktekan prinsip ketaatan terhadap aturan tatanan norma baru dengan senantiasa menjaga jarak dan memakai alat perlindungan diri sebagai bentuk antisipasi terhadap potensi penularan COVID-19, hal ini dikarenakan adanya aturan tatanan normal baru yang diberlakukan oleh penyedia tempat hiburan akan berjalan optimal apabila seorang individu yang tengah melakukan liburan menjadi bagian dalam kesuksesan penyelenggaraan aturan tersebut.

Uraian mengenai tatanan normal baru sebagaimana telah dijelaskan di atas mengkonstruksikan pemahaman bahwa tatanan normal baru terikat langsung dengan perilaku baru dalam kegiatannya berinteraksi sosial di ruang publik, perbedaan norma yang harus ditaati dan dilaksanakan dengan sebelum adanya penyebaran COVID-19 dalam tatanan kehidupan baru merefleksikan adanya upaya untuk tetap melakukan aktivitas dengan tetap memperhatikan kesiapsiagaan terhadap penularan COVID-19. Adapun model perilaku dari seorang individu dikaitkan dengan tatanan norma baru yang harus dilakukan secara bersama-sama dalam berbagai lingkungan dapat dijelaskan melalui tabel berikut ini:

Tabel 1. Model Perilaku Baru dalam Tatanan Normal Baru

\begin{tabular}{ll}
\hline \multicolumn{1}{c}{ Lingkungan } & Model Perilaku \\
\hline Keluarga Inti & Keluarga menjadi awal dari membangun pemahaman akan adanya tatanan \\
normal baru, lingkungan keluarga harus menjadi tempat pertama seorang \\
individu memahami dan mempraktikan tatanan normal baru. Model perilaku \\
yang harus diterapkan dalam tatanan normal baru antara lain, yaitu: \\
- Menerapkan perilaku sehat dan bersih di rumah seperti membersihkan tiap \\
ruangan secara berkala, membuka jendela untuk sirkulasi udara yang baik, \\
tidak membawa barang-barang yang sudah diletakan di ruang publik ke dalam \\
rumah yang memungkinkan terinfeksi COVID-19. \\
- Mencuci tangan dan kaki ketika sudah melakukan aktivitas atau berinteraksi \\
sosial di ruang publik. \\
- Mensterilkan tubuh dan pakaian setelah berada di ruang publik dengan hand- \\
sanitizer atau disinfektan.
\end{tabular}


- Sigap dan waspada terhadap anggota keluarga yang memiliki gejala terinfeksi COVID-19.

Tetangga/Kompleks Intensitas interaksi sosial yang ada di lingkungan perumahan sebelum adanya
COVID-19 harus disikapi dengan bijak yang mana perilaku yang harus ditunjukan antara lain, yaitu:

- Mengurangi interaksi sosial dengan tetangga diluar hal-hal yang bersifat penting dan mendesak.

- Mengoptimalkan penggunaan interaksi virtual/pemanfaatan TIK dibanding interaksi fisik/tatap muka.

- Menjaga jarak apabila melakukan interaksi sosial serta menggunakan alat perlindungan diri seperti memakai masker mulut.

Kerabat/Saudara Berkunjung ke tempat kerabat/saudara atau menerima kunjungan dari kerabat/saudara sebelum adanya COVID-19 wajar dilakukan, dalam tatanan normal baru maka perilaku yang harus ditujukan antara lain, yaitu:

- Mengintensifkan silaturahmi secara virtual/pemanfaatan TIK dibanding interaksi fisik/tatap muka.

- Menerima kunjungan kerabat/saudara apabila dirasa penting/mendesak.

- Mempersingkat waktu dalam aktivitas silaturahmi.

- Menjaga jarak apabila melakukan interaksi serta menggunakan alat perlindungan diri seperti memakai masker mulut.

Tempat Kerja Lingkungan kerja menjadi tempat seorang individu melakukan interaksi secara intens dalam waktu yang lama sehingga pola perilaku yang dilakukan harus berbeda dalam tatanan normal baru yang mana seorang individu harus berperilaku antara lain, yaitu:

- Menjaga lingkungan kerja agar tetap bersih, seperti di ruang kerja, meja kerja dan kursi kerja.

- Mengurangi interaksi fisik dengan rekan kerja.

- Mengoptimalkan penggunaan media komunikasi virtual/pemanfaatan TIK.

- Meminimalisir penggunaan alat kerja bersama, seperti peralatan tulis menulis (pensil, penghapus dan lain sebagainya).

- Membawa makanan dan minuman sendiri.

- Menjaga jarak apabila melakukan interaksi serta menggunakan alat perlindungan diri seperti memakai masker mulut.

Tempat Pemenuhan

Kebutuhan Pokok
Kebutuhan pokok merupakan bagian yang tidak dapat dipisahkan dalam kehidupan manusia, meskipun demikian dalam menjalankan tatanan normal baru aktivitas pemenuhan kebutuhan pokok harus diikuti dengan perilaku baru yang antara lain, yaitu:

- Mengoptimalkan melalui pengantaran jasa transportasi daring/online. 
- Apabila harus berbelanja langsung, persiapkan rencana dan menyusun daftar belanjaan agar mempersingkat waktu belanja.

- Minimalkan kontak langsung dengan penjual.

- Menjaga jarak apabila melakukan interaksi baik terhadap penjual maupun terhadap sesama pembeli, serta menggunakan alat perlindungan diri seperti memakai masker mulut.

- Optimalkan cara pembayaran secara elektronik dibanding dengan uang secara langsung.

Tempat Hiburan Tempat hiburan merupakan bagian dari gaya hidup yang mana setiap orang memiliki lokasi hiburan dengan intensitas yang berbeda-beda, perilaku seorang individu dalam berkunjung ke tempat hiburan dengan tetap mentaati tatanan normal baru antara lain, yaitu:

- Melakukan liburan dengan jumlah anggota yang sedikit, seperti hanya keluarga inti saja.

- Memilih tempat liburan yang direkomendasikan oleh pengunjung/wisatawan sebelumnya bahwa tempat liburan tersebut menerapkan protokol kesehatan aman dari COVID-19 secara konsisten.

- Memilih tempat hiburan yang memiliki interaksi sosial yang rendah.

- Memilih fasilitas liburan yang menjamin kebersihan dan kesehatan.

- Menjaga jarak apabila melakukan interaksi serta menggunakan alat perlindungan diri seperti memakai masker mulut.

Sumber: Analisis Penulis, 2020.

Berdasarkan kepada tabel tersebut diatas, seorang individu dalam melakukan aktivitasnya memerlukan moda transportasi, menjadi pertanyaan kemudian yaitu mengapa moda transportasi tidak secara tegas dimasukan kedalam lingkungan kegiatan individu? Merespons pertanyaan tersebut maka hakekatnya moda transportasi dibagi menjadi 2 (dua) jenis, yaitu moda transportasi pribadi dan moda transportasi umum. Bagi warga masyarakat yang memiliki moda transportasi pribadi maka interaksi yang dilakukan ketika berada dalam kendaranaan tersebut didasarkan kepada kegiatan bersama dengan keluarga inti seperti suami/isteri dan anak sehingga upaya yang dilakukan dalam meminimalisir penyebaran COVID-19 terkait dengan upaya individu terhadap kesehatan diri dan keluarganya yang mana satu anggota keluarga akan mengetahui secara pasti kondisi kesehatan dari anggota keluarga lainnya.

Apabila seorang individu menggunakan transportasi umum maka berlaku tatanan sosial baru yang harus dipatuhi oleh individu bersangkutan yang mana tidak dimungkinkan lagi 
berperilaku sama seperti sebelum adanya COVID-19, perilaku yang harus ditunjukan antara lain yaitu meminimalisir penggunaan kendaraan umum yang diperuntukan untuk keperluan penting atau mendesak, selama berada di fasilitas publik dan selama menggunakan kendaraan umum untuk senantiasa menjaga jarak dengan orang lainnya, meminimalisir interaksi sosial serta menggunakan alat perlindungan diri seperti memakai masker mulut, mencuci tangan dan mensterilkan alat perlengkapan ketika sudah keluar dari kendaraan umum.

Uraian tersebut di atas mengkonstruksikan pemahaman bahwa tatanan normal baru akan mengubah perilaku seorang individu dalam interaksinya dengan orang lain di ruang terbuka baik dalam kelompok dengan jumlah sedikit maupun dalam kelompok dengan jumlah yang besar, hal ini menjadi konsekuensi dari individu atau masyarakat untuk mentaati setiap aturan yang telah ditetapkan dalam kebijakan tatanan normal baru guna mendukung upaya penanggulangan COVID-19, usaha merubah perilaku tersebut pada hakekatnya mengubah pandangan dan pola hidup menjadi lebih sehat sehingga menjamin diri sendiri dan orang yang berada dan berintaksi dengan individu tersebut agar tetap sehat dan terbebas dari penyebaran COVID-19.

\section{Tantangan dalam Penerapan Tatanan Normal Baru Dalam Konteks Sosial Kemasyarakatan}

Tatanan normal baru pada hakekatnya merupakan bentuk kebijakan yang dibuat oleh pemerintah dalam merespons penyebaran COVID-19, sehingga tantangan yang muncul merupakan bagian permasalahan dalam proses implementasi kebijakan publik yang menurut ahli dalam proses pelaksanaan kebijakan publik terdapat faktor-faktor yang mendorong dan menghambat, hal ini sebagaimana diutarakan oleh Grindle (1980) yang menyatakan bahwa keberhasilan dalam pelaksanaan kebijakan publik didasarkan kepada isi kebijakan (content of the policy) dan lingkungan kebijakan (context of the policy), sedangkan menurut Edward III terdapat 4 (empat) faktor yang mempengaruhi keberhasilan pelaksanaan kebijakan publik yaitu faktor komunikasi, sumber daya, disposisi dan struktur birokrasi (Winarno, 2002). Pemahaman ahli tersebut menunjukan bahwa faktor-faktor yang muncul berkorelasi dengan tantangan yang ada dalam implementasi kebijakan publik.

Berdasarkan kepada pemahaman tersebut, maka kebijakan tatanan normal baru akan dihadapkan kepada berbagai tantangan yang mana pada akhirnya akan menentukan apakah 
kebijakan tersebut akan berjalan sesuai dengan harapan dan tujuan awal yang telah ditetapkan atau sebaliknya. Beberapa tantangan dalam pelaksanaan kebijakan tatanan normal baru yang dikaitkan secara langsung dengan kehidupan sosial kemasyarakatan dapat dijelaskan melalui gambar berikut ini:

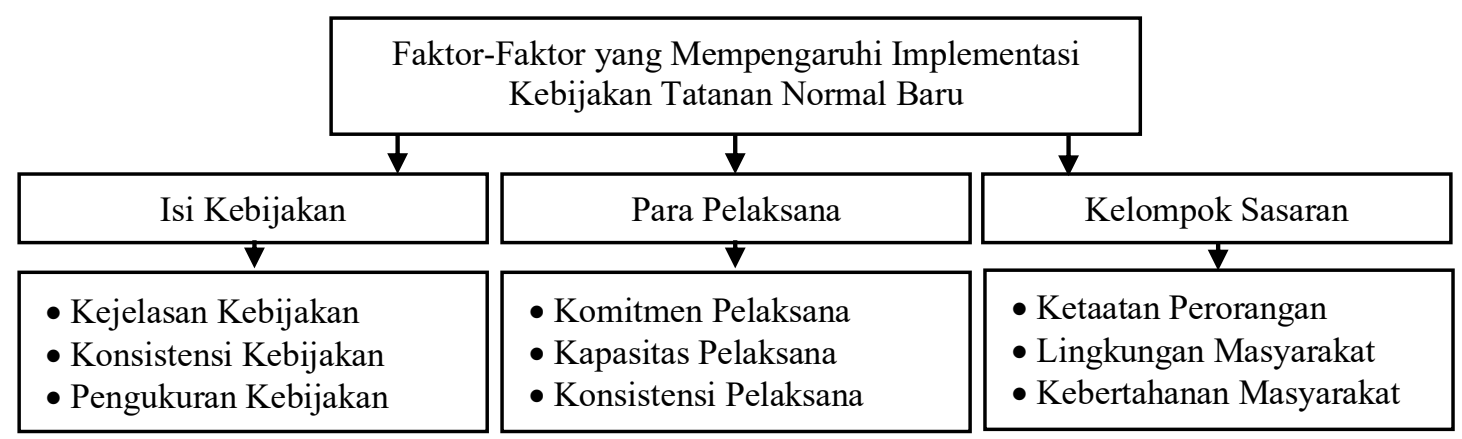

Gambar 2.

Faktor-faktor yang Mempengaruhi Implementasi Kebijakan Tatanan Normal Baru

(Sumber: Analisis Penulis, 2020)

Berdasarkan kepada gambar tersebut diatas, maka setidaknya terdapat 3 (tiga) faktor yang mempengaruhi implementasi kebijakan tatanan normal baru yaitu faktor isi atau substansi kebijakan, faktor para pelaksana atau implementer, faktor kelompok sasaran yang dalam hal ini masyarakat pada umumnya. Adapun penjelasan ketiga faktor tersebut dapat dijelaskan sebagai berikut:

1. Faktor isi atau substansi kebijakan

Isi atau atau substansi kebijakan merupakan elemen yang paling penting dalam suatu kebijakan. Dalam isi kebijakan diatur mengenai pokok-pokok kebijakan yang harus dilaksanakan beserta dengan peran dari para pelaksana dan siapa yang menjadi kelompok sasaran (Agustino, 2008). Dikaitkan dengan implementasi kebijakan tatanan normal baru setidaknya terdapat tiga dimensi yang mempengaruhi implementasi kebijakan tersebut agar dapat terlaksana dengan baik, yaitu: Pertama, kejelasan kebijakan. Kedua, konsistensi kebijakan. Ketiga, pengukuran kebijakan. Adapun penjelasan mengenai ketiga dimensi tersebut dapat dijelaskan sebagai berikut: 
Dimensi kejelasan kebijakan, sebuah kebijakan akan dapat terlaksana dengan baik apabila mengatur secara jelas hal-hal yang akan dilaksanakan mulai dari siapa saja para pelaksana sampai dengan siapa saja kelompok sasaran. Dikaitkan dengan pemahaman tersebut maka dalam konteks pelaksanaan kebijakan tatanan normal baru harus diuraikan secara jelas mulai dari para pelaksana kebijakan sampai dengan masyarakat mana yang menjadi kelompok sasaran dalam implementasi kebijakan tatanan normal baru. Adanya kejelasan mengenai isi kebijakan tatanan normal baru didasarkan kepada beberapa alasan yang antara lain, yaitu: Pertama, memberikan kepastian kepada pihak-pihak yang terlibat sebagai bahan pengetahuan dan menjadi panduan akan peran yang harus dilaksanakan sesuai dengan kedudukannya masing-masing. Kedua, memudahkan dalam proses sosialisasi kebijakan tersebut kepada para pemangku kepentingan lainnya sehinga akan memunculkan koordinasi dan sinergitas antar sesama pemangku kepentingan. Ketiga, memudahkan kelompok sasaran yang dalam hal ini masyarakat untuk mengetahui apa yang menjadi keharusan untuk ditaati dalam implementasi kebijakan tatanan normal baru agar kontribusi masyarakat dapat optimal dalam mewujudkan keberhasilan implementasi kebijakan tatanan normal baru.

Dimensi konsistensi kebijakan, pelaksanaan kebijakan tatanan normal baru selain membutuhkan kejelasan substansi juga membutuhkan konsistensi kebijakan yang mana kebijakan yang telah dibuat dan ditetapkan akan dilaksanakan sampai dengan tujuan kebijakan tersebut berhasil dicapai, setelah adanya penilaian maka akan ditentukan apakah kebijakan yang telah dibuat akan dilanjutkan atau digantikan dengan kebijakan yang lain. Inkosistensi kebijakan pelaksanaan tatanan normal baru dapat dicirikan dengan adanya perubahan baik secara parsial seperti adanya perubahan klausul dalam kebijakan yang telah dibuat maupun adanya kebijakan baru yang dibuat guna menggantikan kebijakan yang tengah dilaksanakan, sehingga kebijakan tatanan normal baru menjadi bias atau bahkan memiliki pertentangan antara satu dengan yang lainnya.

Inkonsistensi kebijakan dalam tatanan normal baru harus dapat dihindari oleh pemerintah dikarenakan beberapa hal yang antara lain yaitu: Pertama, kebijakan merupakan respons resmi pemerintah dalam menanggulangi COVID-19 sehingga adanya perubahan kebijakan akan menunjukan ketidakmampuan pemerintah dalam merespons tuntutan masyarakat dalam penanggulangan COVID-19. Kedua, inkonsistensi kebijakan dapat menunjukan kurangnya kapasitas dan kapabilitas pemerintah dalam penanggulangan COVID- 
19, khususnya dalam perencanaan kebijakan dalam mengakomodasi perkembangan masalah COVID-19. Ketiga, inkonsistensi kebijakan berimplikasi kepada ketidakpastian kinerja bagi para pelaksana kebijakan tatanan normal baru sehingga menyebabkan kebijakan tidak berjalan optimal. Keempat, inkonsistensi kebijakan akan menurunkan kepercayaan masyarakat terhadap kebijakan yang telah dibuat oleh pemerintah yang dimungkinkan memunculkan penolakan atau sikap acuh dari masyarakat terhadap kebijakan penanggulangan COVID-19. Kelima, inkonsistensi kebijakan akan menyulitkan proses evaluasi atau penilaian dari kebijakan itu sendiri apakah kebijakan tersebut berhasil atau sebaliknya.

Uraian mengenai inkonsistensi kebijakan sebagaimana dijelaskan tersebut harus menjadi perhatian pemerintah agar implementasi kebijakan tatanan normal baru dilaksanakan secara penuh tanggung jawab agar mampu menghasilkan output kebijakan sebagaimana tujuan yang telah ditetapkan di awal. Unsur pemerintah dari level nasional sampai dengan level desa harus meyakini bahwa kebijakan tatanan normal baru merupakan respons yang tepat dalam penanggulangan COVID-19 yang mana upaya penanggulangan berjalan sinergis dengan keberlanjutan aktivitas masyarakat. Dimensi pengukuran kebijakan, setiap kebijakan memiliki tujuan keberhasilannya masing-masing sebagaimana yang telah ditetapkan di awal, hal tersebut berlaku pula untuk kebijakan tatanan normal baru yang mana harus memiliki ukuran-ukuran keberhasilan yang harus dicapai sehingga akan menjadi pedoman bagi para pelaksana mengenai kontribusi apa yang harus dijalankan agar mencapai tujuan tersebut.

Kebijakan tatanan normal baru bukan hanya sekedar mengatur masyarakat agar menjaga jarak ketika berada di ruang publik dan menggunakan alat perlindungan diri seperti masker mulut, tetapi juga harus memiliki konteks ruang dan waktu sebagai ukuran keberhasilan penerapannya, semisal dalam minggu pertama penerapan kebijakan tatanan norma baru berapa persentase jumlah masyarakat yang akan menggunakan masker mulut ketika berada di ruang publik kemudian dari persentase tersebut dalam minggu keberapa masyarakat akan seluruhnya menggunakan masker.

Pengukuran lainnyapun harus ikut ditetapkan seperti persentase pengurangan infeksi COVID-19, normalisasi kegiatan masyarakat, normalisasi ekonomi dan lain sebagainya yang keseluruhannya akan menggambarkan estimasi sampai dengan batas waktu berapa lama COVID-19 mampu ditanggulangi, dengan begitu konteks ruang dan waktu dalam pelaksanaan 
kebijakan tatanan normal baru dapat diukur keseluruhannya mengingat bahwa tidak akan selamanya masyarakat harus dihadapkan kepada ketaatan mengikuti kebijakan tatanan normal baru tanpa adanya kepastian atau tanpa adanya manfaat yang didapat dari mentaati kebijakan tersebut dalam kurun waktu yang tidak menentu. Hasil pengukuran kebijakan tatanan normal baru akan dijadikan masukan bagi pemerintah dan pemangku kepentingan lainnya untuk menetapkan strategi kebijakan selanjutnya yang akan dibuat sehingga diharapkan adanya kejelasan pengukuran kebijakan tatanan normal baru dapat dijadikan pedoman bagi perbaikan semua aspek kehidupan pasca wabah COVID-19.

\section{Faktor Para Pelaksana}

Para pelaksana dalam implementasi kebijakan publik memegang peran yang penting, hal ini didasarkan kepada alasan bahwa para pelaksana merupakan aktor utama yang akan menggerakan kebijakan agar dapat terlaksana sesuai dengan tujuan yang telah ditetapkan (Akib, 2010; Tachjan, 2008). Dikaitkan dengan kebijakan tatanan normal baru maka para pelaksana bukan saja secara jabatan merupakan bagian dari unsur pemerintah yang ditunjuk untuk melaksanakan kebijakan tatanan normal baru, tetapi juga harus memiliki kecakapan untuk dapat melaksanakan kebijakan sesuai dengan perannya masing-masing. Setidaknya terdapat 3 (tiga) dimensi yang menjadi tantangan dalam aspek aktor pelaksana agar pelaksanaan kebijakan tatanan normal baru dapat berjalan sebagaimana tujuan yang telah ditetapkan, yaitu: Pertama, komitmen pelaksana. Kedua, kapasitas pelaksana. Ketiga, konsistensi pelaksana. Adapun penjelasan dari ketiga dimensi tersebut adalah sebagai berikut:

Dimensi komitmen pelaksana kebijakan, komitmen merupakan kehendak atau keinginan yang kuat untuk dapat melaksanakan kebijakan sesuai dengan kapasitasnya masingmasing (Setyanto, 2011). Dikaitkan dengan implementasi kebijakan tatanan normal baru maka setiap pelaksana yang terlibat harus memiliki komitmen untuk dapat menyukseskan kebijakan tatanan normal baru agar dapat terlaksana dengan baik. Implementasi kebijakan tatanan normal baru membutuhkan komitmen dari para pelaksana dikarenakan keberhasilan tujuan pelaksanaan kebijakan tatanan baru yaitu terciptanya aktivitas kehidupan masyarakat dan terkendalinya penyebaran COVID-19. Apabila komitmen tersebut diabaikan oleh para pelaksana maka tidak menutup kemungkinan upaya penanggulangan COVID-19 tidak akan selesai dalam waktu yang cepat, sehingga komitmen para pelaksana menjadi bagian penting dari keberhasilan pelaksanaan kebijakan tatanan normal baru. 
Dimensi kapasitas pelaksana, kapasitas diartikan sebagai kemampuan para pelaksana kebijakan untuk dapat melaksanakan kebijakan sesuai dengan perannya masing-masing (Alam \& Prawitno, 2015). Dikaitkan dengan implementasi kebijakan tatanan normal baru bahwa setiap pihak atau para pelaksana wajib memiliki kapasitas atau kemampuan untuk dapat menjalankan perannya sesuai dengan kemampuan masing-masing agar kebijakan tatanan normal baru dapat terlaksana sesuai dengan tujuan yang telah ditetapkan bersama dikarenakan para pelaksana mampu untuk menjalankan tugasnya masing-masing.

Tatanan normal baru hakekatnya memiliki 2 (dua) agenda utama yaitu meminimalisir penyebab COVID-19 dan mengembalikan kegiatan masyarakat, didasarkan kepada hal tersebut maka para pelaksana kebijakan tatanan normal baru terdiri dari dua bagian yaitu tenaga medis dan tenaga non medis yang diberikan peran untuk menanggulangi COVID-19 serta aparatur pemerintah yang diberikan peran untuk memastikan kegiatan masyarakat berjalan sesuai dengan protokol kesehatan dalam mewujudkan sikap kesiapsiagaan terhadap penyebaran COVID-29.

Para pelaksana yang berperan menanggulangi COVID-19 seperti dokter, perawat dan lainnya harus memiliki kapasitas sesuai dengan tuntutan dan kebutuhan, begitupula para pelaksana yang berperan untuk memastikan kelancaran kegiatan masyarakat harus memiliki kapasitas sesuai tuntutan dan kebutuhan, para pelaksana kebijakan tatanan normal barus harus mampu menjalin kerjasama secara sinergis agar pelaksanaan peran masing-masing dapat terselenggara dengan lancar dan tujuan kebijakan tatanan normal baru dapat tercapai sesuai dengan tujuan yang telah ditetapkan.

Dimensi konsistensi pelaksana, konsistensi dalam penanggulangan COVID-19 menjadi isu yang menjadi perhatian banyak pihak, termasuk didalanya ketika pemerintah mencanangkan kebijakan tatanan normal baru maka sebagian pihak menyatakan bahwa kebijakan tersebut merupakan bentuk inkonsistensi pemerintah dalam penanggulangan COVID-19, hal ini didasarkan kepada fakta bahwa kebijakan tatanan normal baru disusun oleh pemerintah di awal bulan Juni ketika kasus infeksi COVID-19 di Indonesia secara nasional dirata-ratakan ada lebih dari 500 (lima ratus) kasus infeksi setiap harinya. Kondisi tersebut disikapi oleh sebagian masyarakat dengan sikap pesimis dan penolakan terhadap kebijakan tatanan normal baru, sehingga mempertanyakan keseriusan pemerintah dan konsistensisnya 
dalam penanggulangan COVID-19 (Gugus Tugas Percepatan Penanganan COVID-19, 2020; Hakim, 2020b; Syambudi, 2020).

Uraian mengenai anggapan inkonsistensi pemerintah dalam penanggulangan COVID19 harus menjadi bahan perhatian pemerintah khususnya dalam implementasi kebijakan tatanan normal baru. Pemerintah harus memiliki sikap konsisten terhadap kebijakan tatanan normal baru dan melaksanakan kebijakan tersebut sampai dengan wabah COVID-19 benarbenar dapat diatasi atau setidaknya diminimalisir. Aparat pemerintah yang secara langsung melaksanakan kebijakan tatanan normal baru harus pula memiliki konsistensi yang sama dalam artian akan melaksanakan kebijakan tatanan normal baru sesuai dengan kapasitasnya masingmasing, seperti contoh apabila diketemukan masyarakat yang melanggar kebijakan tatanan normal baru dengan tidak menggunakan masker mulut di ruang publik maka aparat tersebut harus menindak warga masyarakat tersebut tanpa memandang latar belakang status sosial maupun tempat dan waktu diketemukan adanya pelanggaran tersebut.

Sikap konsistensi yang ditunjukan oleh paratur pelaksana pada akhirnya selain akan menjadi contoh bagi masyarakat untuk tetap melaksanakan kebijakan tatanan normal baru juga dapat menumbuhkan sikap simpati masyarakat kepada para pelaksana kebijakan tatanan normal baru sehingga pada akhirnya diharapkan akan mampu mendorong partisipasi masyarakat untuk mentaati kebijakan tatanan normal baru.

\section{Faktor Kelompok Sasaran}

Faktor ketaatan perseorangan, kelompok sasaran terdiri dari individu-individu yang menjadi objek dalam implementasi kebijakan (Tachjan, 2008), dikaitkan dengan tatanan normal baru maka kelompok sasaran merupakan individu bagian dari warga masyarakat yang diharuskan melaksanakan kebijakan tatanan normal baru. Setidaknya terdapat tiga dimensi yang berasal dari faktor kelompok sasaran yang dapat mempengaruhi implementasi kebijakan tatanan normal baru, yaitu: Pertama, ketaatan perseorangan. Kedua, lingkungan masyarakat. Ketiga, kebertahanan masyarakat. Adapun penjelasan dari ketiganya dapat diuraikan sebagai berikut:

Dimensi ketaatan perseorangan, dasar dari keberhasilan implementasi kebijakan tatanan normal baru yaitu dimulai dari ketaatan perseorangan yang mana seseorang dengan 
kesadarannya mau dan mampu melaksanakan kebijakan tatanan normal baru dengan cara mentaati apa yang menjadi ketentuan dalam kebijakan tersebut. Banyak faktor yang mempengaruhi seseorang mentaati kebijakan tatanan normal baru diantaranya yaitu adanya pemahaman mengenai kebijakan tatanan normal baru dan adanya kemauan untuk melaksanakan kebijakan tatanan normal baru.

Pemahaman seseorang terhadap kebijakan tatanan normal baru dapat beragam antar satu orang dengan orang lainnya yang dipengaruhi oleh tingkat pengetahuan, akses terhadap informasi dan intensitas komunikasi dan interaksi dengan orang atau warga masyarakat lainnya, semakin orang banyak mengakses informasi mengenai kebijakan tatanan normal baru dan memiliki intensitas berkomunikasi mengenai masalah kebijakan tatanan normal baru dengan orang lain maka semakin baik pula pengetahuan orang tersebut terhadap kebijakan tatanan normal baru.

Adanya pemahaman yang baik terhadap kebijakan tatanan normal baru belum dapat menjamin adanya adanya kemauan untuk melaksanakan dan mentaati kebijakan tatanan normal baru, hal ini antara lain dipengaruhi oleh beberapa faktor yang antara lain yaitu manfaat apa yang akan diperoleh apabila melaksanakan kebijakan tatanan norma baru dan peluang apa yang bisa didapat dari melaksanakan kebijakan tatanan normal baru. Ketika seseorang menyadari akan adanya manfaat yang diperoleh apabila melaksanakan kebijakan tatanan normal baru maka akan mendorong orang tersebut untuk secara sadar melaksanakan kebijakan tersebut begitu pula sebaliknya, dikarenakan seseorang tersebut memiliki kepentingan terhadap keberhasilan pelaksanaan kebijakan yaitu memperoleh manfaat baik untuk dirinya sendiri maupun untuk orang lain.

Dimensi lingkungan masyarakat, seorang individu memiliki kecenderungan untuk terpengaruhi oleh lingkungan sosial dimana mereka berada atau bertempat tinggal yang pada akhirnya akan turut pula menentukan perilaku dari individu tersebut (Tamara, 2016). Dikaitkan dengan tatanan normal baru maka seorang individu dalam mentaati kebijakan tatanan sosial baru akan turut pula dipengaruhi oleh lingkungannya, apabila lingkungannya mendukung terlaksananya kebijakan tatanan normal baru maka akan mendorong individu untuk turut pula mentaati kebijakan tatanan normal baru dikarenakan lingkungan tempatnya berada dalam keadaan kondusif terhadap pelaksanaan kebijakan, begitu pula sebaliknya apabila lingkungan 
tidak mendukung bagi terlaksananya kebijakan tatanan sosial baru maka individu yang menjadi bagian dari lingkungan tersebut akan memiliki kecenderungan untuk acuh dan tindak mentaati kebijakan tatanan normal baru.

Kondisi tersebut sejalan dengan keadaan empiris selama pelaksanaan penanggulangan COVID-19 yang mana ketika suatu lingkungan yang masyarkatanya konsisten maka akan berpengaruh kepada individu yang ada di lingkungan tersebut, seperti adanya kebijakan lockdown di satu desa guna menanggulangi COVID-19, maka warga masyarakat yang ada di desa tersebut akan turut pula mentaati kebijakan tersebut (Anugrahanto, 2020), hal serupa berlaku sebaliknya ketika lingkungan tidak konsisten mentaati kebijakan penanggulangan COVID-19 maka individu yang ada di lingkungan tersebut memiliki kecenderungan untuk tidak mentaati kebijakan tersebut. Didasarkan kepada hal tersebut maka tantangan keberhasilan pelaksanaan kebijakan tatanan normal baru akan turut pula dipengaruhi oleh lingkungan masyarakat dimana seorang individu bertempat tinggal. Dengan demikian maka menjadi tanggung jawab pemerintah khususnya di tingkat terendah yang langsung berhadapan dengan masyarakat yaitu Pemerintah Desa dan Kelurahan untuk dapat memastikan lingkungan yang menjadi wilayah administratifnya melaksanakan kebijakan tatanan normal baru.

Faktor kebertahanan masyarakat, masyarakat dalam masa pandemi COVID-19 mengalami kesulitan ekonomi, khususnya dialami oleh sektor ekonomi informal yang mana adanya pembatasan sosial dan pelaksanaan PSBB di beberapa daerah yang memaksa banyak usaha harus ditutup dikarenakan tidak termasuk kedalam pengecualian usaha yang diperbolehkan, kondisi tersebut mengakibatkan penghasilan masyarakat berkurang atau terhenti sehingga sebagian masyarakat melakukan pinjaman uang kepada saudara atau kerabat bahkan sebagian dari mereka menjual barang berharga yang dimiliki, usaha yang dilakukan tersebut guna memenuhi kebutuhan pokok agar dapat tetap bisa menyelenggarakan penghidupannya (Prasetya, 2020).

Pemberlakuan tatanan normal baru yang mengharuskan masyarakat untuk melaksanakan kegiatan didasarkan kepada kesiagaan terhadap COVID-19 berimplikasi kepada cara masyarakat dalam berinteraksi dengan orang lain ketika sedang berada di ruang publik. Masyarakat yang bekerja di suatu kantor akan menjalani aktivitasnya dengan didasarkan kepada kebijakan tatanan normal baru seperti menjaga jarak dan menggunakan alat 
perlindungan diri, begitu pula dengan masyarakat yang bekerja di sektor informal seperti para pedagang yang berada di pasar.

Ketahanan masyarakat selama pelaksanaan PSBB di beberapa daerah seperti di DKI Jakarta menunjukan bahwa tidak semua masyarakat mematuhi kebijakan tersebut, di sektor informal seperti aktivitas perdagangan diawal-awal pemberlakuan kebijakan PSBB masyarakat taat, tetapi setelah memasuki PSBB tahap ke 2 (dua) maka masyarakat mulai mengindahkan kebijakan PSBB seperti yang terjadi di daerah pusat perdagangan Tanah Abang yang mana sebagian pedagang membuka toko meskipun ada kebijakan PSBB yang melarang membuka toko dan berjualan pakaian (Pratama, 2020). Kondisi ketahanan masyarakat dalam pelaksanaan PSBB harus dijadikan penilaian terhadap kebijakan tatanan sosial baru, sejauhmana masyarakat akan tetap mentaati kebijakan tatanan normal baru dihadapkan dengan kondisi adanya tuntutan pemenuhan kebutuhan yang tidak sepenuhnya bisa digantikan dengan adanya penyaluran bantuan sosial bagi masyarakat terdampak COVID-19.

Peran pemerintah dalam konteks ini harus dapat memberikan jaminan bahwa adanya kebijakan tatanan normal baru akan sejalan dengan kemudahan melakukan aktivitas/usaha bagi masyarakat sama seperti sebelum adanya wabah COVID-19. Apabila tidak dapat terwujud, maka besar kemungkinan masyarakat mengindahkan kebijakan tatanan normal baru dan memilih melanjutkan kegiatannya masing-masing agar dapat tetap dapat memenuhi kebutuhannya. Berdasarkan kepada penjelasan mengenai faktor-faktor yang mempengaruhi implementasi kebijakan tatanan normal baru maka dapat dikonstruksikan suatu pemahaman bahwa kebijakan tatanan sosial baru tidak hanya sebatas memberikan alternatif solusi menjalankan aktivitas di tengah wabah COVID-19 dengan memperhatikan akan potensi penularan COVID-19 tersebut, tetapi juga implementasi kebijakan tatanan normal baru harus pula memberikan kepastian kepada masyarakat akan kemudahan menjalankan usaha pemenuhan kebutuhannya sama seperti sebelum adanya wabah COVID-19. Kebijakan tatanan normal baru dalam pelaksanaan kedepannya harus pula melihat berbagai faktor yang ada di masyarakat, sehingga diharapkan tidak akan menimbulkan pertentangan atau penolakan dari masyarakat.

Pemerintah dan masyarakat harus menjadi pihak yang diuntungkan dalam pelaksanaan tatanan normal baru, pemerintah harus menjadi pihak yang diuntungkan dari adanya 
keberhasilan penanggulangan COVID-19 dan keberhasilan mendorong keberlanjutan aktivitas masyarakat di tengah-tengah adanya penyebaran COVID-19. Di sisi masyarakat, pelaksanaan kebijakan tatanan normal baru harus dapat menguntungkan yaitu dengan adanya kebijakan tatanan normal baru maka aktivitas kehidupan masyarakat dapat berlangsung, dengan begitu akan memunculkan sinergitas antara upaya penanggulangan COVID-19 dengan keberlanjutan hidup masyarakat.

\section{KESIMPULAN}

COVID-19 telah memberi perubahan terhadap kehidupan sosial kemasyarakatan, adanya pemberlakuan tatanan normal baru merubah pola interaksi sosial yang harus didasarkan kepada protokol kesehatan aman dari penyebaran COVID-19. Perubahan tersebut terkait kepada interaksi individu dengan lingkungannya yang terdiri dari lingkungan keluarga inti, lingkungan kerabat, lingkungan tempat kerja, lingkungan tempat pemenuhan kebutuhan pokok dan lingkungan tempat hiburan. Dalam konteks lingkungan keluarga setiap anggota keluarga harus memahami dan mempraktekan tatanan normal baru dengan menerapkan perilaku hidup sehat dan bersih di dalam rumah. Dalam konteks interaksi sosial di ruang publik mulai dari interaksi dengan tetangga sampai kepada interaksi dengan rekan kerja diorientasikan kepada interaksi sosial yang menjaga jarak satu dengan yang lainnya serta menggunakan alat pelindung diri seperti menggunakan masker mulut. Perubahan ini didasarkan kepada sikap kesigapan terhadap potensi penyebaran COVID-19.

Praktek pemberlakuan tatanan normal baru tersebut secara empiris dihadapkan kepada beberapa tantangan yang diantaranya menyangkut kepada tiga aspek yaitu: Pertama, menyangkut isi kebijakan tatanan normal baru yang didalamnya memuat aturan-aturan atau protokol kesehatan yang harus dilaksanakan. Kedua, menyangkut para pihak-pihak yang ditunjuk untuk melaksanakan tatanan normal baru dan ketiga menyangkut masyarakat sebagai kelompok sasaran yang harus mentaati dan mempraktekan tatanan normal baru baik ketika berada di lingkungan keluarga maupun ketika berada di ruang publik. Kepatuhan dan ketaatan terhadap kebijakan tatanan normal baru akan memberi implikasi kepada kehidupan sosial kemasyarakatan baru yang didasarkan kepada adanya kesadaran akan pencegahan penyebaran COVID-19. 


\section{DAFTAR PUSTAKA}

Agustino, L. (2008). Dasar-Dasar Kebijakan Publik. Bandung: Alfabeta.

Akib, H. (2010). Implementasi Kebijakan: Apa, Mengapa dan Bagaimana. Jurnal Administrasi Publik, 1(1), 1-11.

Alam, A. S., \& Prawitno, A. (2015). Pengembangan Kapasitas Organisasi dalam Peningkatan Kualitas Pelayanan Publik Dinas Kehutanan dan Perkebunan Kabupaten Bone. Government: Jurnal Ilmu Pemerintahan, 8(2), 93-104.

Alwi, H. (2007). Kamus Besar Bahasa Indonesia. Jakarta: Balai Pustaka.

Angkasawati. (2015). Masyarakat Desa. Jurnal Publiciana, 8(1), 1-23.

Anugrahanto, N. C. (2020). "Lockdown” Kampung, Cara Warga Lereng Merapi Perangi Pandemi. Retrieved April 2, 2020, from https://bebas.kompas.id/baca/bebasakses/2020/03/28/pengawasan-pergerakan-warga-diperketat/

Center for Tropical Medicine UGM. (2020). Desa Tangguh COVID-19. Yogyakarta: Universitas Gadjah Mada.

Creswell, J. W. (2007). Qualitative Inquiry and Reseach Design: Choosing Among Five Approaches. Thousand Oaks: Sage Publications.

David, C., Collins, D., \& Winfield, N. (2020). New 'normal': Countries worldwide slowly get back to business amid coronavirus. Retrieved June 2, 2020, from https://globalnews.ca/news/6962652/coronavirus-new-normal-countries-reopen/

Fang, Ja., Weedon, A., \& Handley, E. (2020). Coronavirus COVID-19's Wuhan Lockdown: A Month On.

Frank, L. K. (1944). What Is Social Order? American Journal of Sociology, 49(5), 470-477. Retrieved from http://www.jstor.org/stable/2770484

Grindle, M. S. (1980). Politics and Policy Implementation in The Third World. New Jersey: 
Princeton University Press.

Gugus Tugas Percepatan Penanganan COVID-19. (2020). Peta Sebaran COVID-19. Jakarta. Retrieved from https://covid19.go.id/peta-sebaran

Gunia, A. (2020). Will the Coronavirus Ever Go Away? Here's What One of the WHO's Top Experts Thinks. Retrieved June 2, 2020, from https://time.com/5805368/willcoronavirus-go-away-world-health-organization/

Hakim, R. N. (2020a). Kepala Bappenas Sebut Syarat "New Normal” Tak Hanya Turunnya Penularan Covid-19. Retrieved June 2, 2020, from https://nasional.kompas.com/read/2020/05/28/00160071/kepala-bappenas-sebutsyarat-new-normal-tak-hanya-turunnya-penularan-covid

Hakim, R. N. (2020b). Saat Pemerintah Persiapkan Fase New Normal di Tengah Pandemi Covid-19. Retrieved June 1, 2020, from https://nasional.kompas.com/read/2020/05/27/08141631/saat-pemerintah-persiapkanfase-new-normal-di-tengah-pandemi-covid-19

Hayati, A., \& Yuswandi, H. (2019). Pola Hubungan Ketetanggaan di Masyarakat Urban: Studi Kasus di Kampung Osing, Jember. E-Sospol, VI(1), 14-20.

Keogh, B. (2020). Coronavirus Weekly: Balancing a 'new normal' While Keeping COVID-19 in Check. Retrieved June 2, 2020, from https://theconversation.com/coronavirusweekly-balancing-a-new-normal-while-keeping-covid-19-in-check-138577

Kusumadewi, L. R. (2010). Kembalinya Subyek: Sosiologi Memaknai Kembali Multikulturalisme. Masyarakat: Jurnal Sosiologi, 15(2), 61-84.

Munir, M. (2015). Sistem Kekerabatan Dalam Kebudayaan Minangkabau: Perspektif Aliran Filsafat Strukturalisme Jean Claude Levi-Strauss. Jurnal Filsafat, 25(1), 1-31.

Mustafa, H. (2011). Perilaku Manusia Dalam Perspektif Psikologi Sosial. Jurnal Administrasi Bisnis (JAB), 7(2), 143-156.

Nawawi, H. (2007). Metode Penelitian Bidang Sosial. Yogyakarta: Gajah Mada Press. 
Prasetya, E. (2020). Dampak Covid-19 Sangat Dirasakan Masyarakat, Apalagi Diberlakukan PSBB. Retrieved May 31, 2020, from https://www.merdeka.com/peristiwa/dampakcovid-19-sangat-dirasakan-masyarakat-apalagi-diberlakukan-psbb.html

Pratama, K. R. (2020). Pasar Tanah Abang Disesaki Warga di Tengah PSBB, Satpol PP Kewalahan. $\quad$ Retrieved $\quad$ May 31, 2020, from https://megapolitan.kompas.com/read/2020/05/18/20344461/pasar-tanah-abangdisesaki-warga-di-tengah-psbb-satpol-pp-kewalahan

Sari, N. (2020). Kini Ada 273 Pedagang di 43 Pasar Jakarta Positif Covid-19, Berikut Daftarnya. July 15, 2020, from https://megapolitan.kompas.com/read/2020/07/14/06191141/kini-ada-273-pedagangdi-43-pasar-jakarta-positif-covid-19-berikut?page=all

Setyanto, B. N. (2011). Hubungan Antara Komitmen, Kepemimpinan Dan Kesejahteraan Terhadap Fraud Dalam Manajemen Pendidikan Di Blpt Yogyakarta. Universitas Negeri Yogyakarta.

Sugiyono. (2013). Metode Penelitian Pendidikan Pendekatan Kuantitaif, Kualitatif, dan R\&D. Bandung: Alfabeta.

Syambudi, I. (2020). Di Balik Penolakan Muhammadiyah terhadap New Normal Jokowi. Retrieved June 1, 2020, from https://tirto.id/di-balik-penolakan-muhammadiyahterhadap-new-normal-jokowi-fDEn

Tachjan. (2008). Implementasi Kebijakan Publik. Bandung: AIPI Bandung-Puslit KP2W Lemlit UNPAD.

Tamara, R. M. (2016). Peranan Lingkungan Sosial Terhadap Pembentukan Sikap Peduli Lingkungan Peserta Didik Di Sma Negeri Kabupaten Cianjur. Jurnal Pendidikan Geografi, 16(1), 44-55.

Winarno, B. (2002). Teori dan Proses Kebijakan Publik. Yogyakarta: Media Pressindo.

World Health Organization. (2020). Statement - Transition to a 'new normal' during the 
COVID-19 pandemic must be guided by public health principles. Jenewa. Retrieved from http://www.euro.who.int/en/health-topics/health-emergencies/coronavirus-covid19/statements/statement-transition-to-a-new-normal-during-the-covid-19-pandemicmust-be-guided-by-public-health-principles

Yigibalom, L. (2013). Peranan Interaksi Anggota Keluarga Dalam Upaya Mempertahankan Harmonisasi Kehidupan Keluarga Di Desa Kumuluk Kecamatan Tiom Kabupaten Lanny Jaya. Acta Diurna Komunikasi, 2(4). 